\title{
THE HANDLING OF TORT CLAIMS AGAINST THE FEDERAL GOVERNMENT
}

\author{
Alexander HoltzofF*
}

The doctrine that the sovereign is not subject to suit in his own courts, except to the extent to which he consents to be sued, was a principle of the common law at the time of the adoption of the Constitution. Consequently, it has been accepted as an unquestioned rule since the establishment of the Republic that no suit may be maintained against the United States unless the Congress consents that the Government be sued and waives the sovereign immunity. In such event, an action will lie against the Government only in the class of cases and under the conditions specified in the Act of Congress. ${ }^{x}$

Because of a lack of a judicial remedy with respect to claims against the Government, the custom of appealing to the legislature for relief originated in the very first Congress. The first private bill passed by the Congress of the United States for the purpose of adjusting an individual claim became law on June I4, I790. It provided for the remission of duties owed by Thomas Jenkins \& Company on a shipment that had been destroyed by fire. ${ }^{2}$ As early as April 13, I792, a private act of Congress recognizing a tort claim against the United States became law. It provided for compensation to the Corporation of Trustees of the Public Grammar School and Academy of Wilmington, Delaware, for the use and occupation of the school and the damages done to it by the troops of the United States during "the late war."3

Presumably for want of any other remedy, it became the customary practice to handle claims against the Government by special legislation. Business of this type gradually grew in volume to a point at which it became a serious burden on the members of the Congress. In the diary of John Quincy Adams we find the following entry for February 23, I832:4

At the House, Drayton had offered a resolution for altering the rule of the House which devotes Fridays and Saturdays to the consideration of private business, so that Saturday alone should be thus specially appropriated. Various amendments were proposed, and, after a discussion of two hours or more, they were all rejected, as well as the motion itself.

* A.B., I908, M.A., I909, Columbia University; LL.B., I9Ir, Columbia Law School. Special Assistant to the Attorney General of the United States since r924. Member of the American Bar Association and Federal Bar Association. Author: NEw Federal Procedurè and the Courts (1940); co-author: FederaI Procedural Forms (I940). Contributor to legal periodicals.

${ }^{1}$ Cohens v. Virginia, 6 Wheat. 264 (U. S. I82I); U. S. v. Clarke, 8 Pet. 436 (U. S. I834); U. S. v. O'Keefe, Ir Wall. 178, I82 (U. S. 187I); U. S. v. Lec, 106 U. S. 196,206 (1882).

${ }^{2} 6$ Stat. 2. ${ }^{3} 6$ Stat. 8. 8 Memolrs of John Quincy Adams (1876) $479-480$. 
There ought to be no private business before Congress. There is a great defect in our institutions by the want of a Court of Exchequer or Chamber of Accounts. It is judicial business, and legislative assemblies ought to have nothing to do with it. One half of the time of Congress is consumed by it, and there is no common rule of justice for any two of the cases decided. A deliberative assembly is the worst of all tribunals for the administration of justice.

The condition of which Adams complained, nevertheless, continued for almost another quarter of a century. On February 24, I855, however, the Court of Claims was established, with jurisdiction over claims against the United States founded upon any law of Congress or upon any contract, express or implied.

For the first time a judicial remedy, general in kind, was accorded to claimants against the United States. It will be observed, however, that tort claims were outside of the scope of the act. Moreover, the law contained a serious defect in that the authority of the newly established tribunal was limited to submitting findings of fact and its opinion to the Congress, with a bill to carry its recommendation into effect, if the conclusion was in favor of the claimant. The court was not empowered to render any judgment.

In spite of the stress and strain attendant upon the great internecine conflict then raging, Abraham Lincoln, in his Annual Message to the Congress, submitted on December 3, I86I, alluded to this subject and recommended that more convenient means be provided for the adjustment of claims against the Government. He called attention to the fact that while the Court of Claims had proved to be an effective and valuable means of investigation, it, nevertheless, failed in a great degree to effect the object of its creation, for want of power to make its judgments final. In the course of the discussion of this topic, he made the following pungent and significant observations:

It is as much the duty of Government to render prompt justice against itself in favor of citizens as it is to administer the same between private individuals. ${ }^{6}$

By the Act of March 3, I863, the Court of Claims was transformed into a real judicial tribunal with authority to render judgments. The statute again restricted the jurisdiction of the court, however, to actions in contract, express or implied, and in addition, to claims based upon the Constitution, Acts of Congress or regulations of executive departments. Claims sounding in tort were expressly excluded. This limitation remains in the law to this day. ${ }^{7}$

It is well settled that no action in tort lies against the United States in the Court of Claims. ${ }^{8}$ This prohibition may not be avoided by waiving the tort and suing in assumpsit. While suit may be brought against the United States on an implied contract, as well as on an express contractual obligation, it has been held that this grant of jurisdiction relates only to contracts implied in fact and does not extend to con-

io Stat. 612.

'6 Rrchardson, Messages and Papers of the Presidents (I897) 51.

${ }^{7} 28$ U. S. C. $\$ 250$ (1940).

${ }^{8}$ Schillinger v. U. S., I55 U. S. 163 (1894). 
tracts implied in law. ${ }^{9}$ The courts have held, however, that if the Government takes property lawfully by eminent domain, a contract implied in fact arises to pay just compensation, and, therefore, an action to recover the value of property so taken by the United States may be maintained in the Court of Claims. ${ }^{10}$

The gap in the statutory scheme, which enables the Government to maintain its immunity against suit in tort, while being subject to suit in contract, has frequently been a source of considerable difficulty and on occasion has led the Congress to waive the governmental exemption temporarily in respect to specified groups of claims. For example, by the Act of March 3, I863, ${ }^{11}$ owners of property that had been abandoned to or captured by Union troops during the Civil War, and which had been taken into the possession of agents of the Treasury Department, were authorized to maintain suit in the Court of Claims for the proceeds of the sale of such property, provided they could show that they had never given aid or comfort to "the present rebellion." A statute of limitations of two years "after the suppression of the rebellion" was included in the act. By the Act of March $3,189 \mathrm{I},{ }^{12}$ jurisdiction was granted to the Court of Claims to entertain claims for property of citizens of the United States taken or destroyed by Indians in amity with the United States, without just cause or provocation on the part of the owner and not returned or paid for.

In I9ro, Congress passed an act permitting suits to be brought against the United States in the Court of Claims for compensation for the use of patents. ${ }^{13}$ Because of the peculiar wording of the statute, it has been intimated that a suit under this provision is in effect an action to recover.just compensation for the taking of property by eminent domain, on the theory that by using a patented invention the Government by implication takes a non-exclusive license to use the invention. ${ }^{14}$ Nevertheless, whatever may be the legal justification for the proceeding, the fact remains that a judicial remedy is accorded against the Government to recover demages or compensation for the infringement of a patent by the United States. Such infringement, although not a common law tort, because it is based entirely on a statutory right, is, nevertheless, in the nature of a tortious act, and, therefore, the discussion of tort liability of the United States would hardly be complete without an allusion to the Act of I9ro, which permits the Government to be sued in case of patent infringement by its officers and employees.

A far-reaching step was taken in 1920 when the Congress permitted libels in personam to be brought against the United States in the federal district courts, in respect to admiralty and maritime torts, if the guilty vessel was a merchant ship or a tugboat, owned or operated by the Government. ${ }^{15}$ Five years later this jurisdiction was extended to admiralty and maritime torts involving public vessels of the United

\footnotetext{
${ }^{9}$ Harley v. U. S., I98 U. S. 229 (Ig05); U. S. v. Minn. Mutual Investment Co., 271 U. S. 212 (1926).

${ }^{10}$ Grant v. U. S., I Ct. Cl. 4I, 50 (I863); Great Falls Mfg. Co. v. U. S., I6 Ct. Cl. I60 (I880), affd II2 U. S. 645 (I884).

${ }^{22}$ i2 Stat. 820. ${ }^{12} 26$ Stat. 85I.

${ }^{13} 36$ STAT. 851 (I910), as amended by 40 Stat. 705 (IgI8), 35 U. S. C. $\$ 68$ (1940).

14 Crozier v. Fried. Krupp A. G., 224 U. S. 290 (Igrz).

${ }^{15}{ }_{41}$ STAT. 525 (I920), 46 U. S. C. $\$ 742$ (I940).
} 
States. ${ }^{16}$ By these two acts, jurisdiction was granted to the district courts of the United States in all cases of admiralty and maritime torts in which the guilty vessel is owned or operated by the Government.

With the foregoing bird's-eye view of the historical development of judicial remedies against the United States as a basis, attention may now be directed to the existing modes of handling tort claims against the Government, for it must be remembered that the absence of a judicial remedy is not to give rise to an inference that such claims are not adjusted at all. The discussion of existing remedies will be divided into three categories: first, cases in which a judicial remedy is accorded; second, cases in which administrative agencies are authorized to make administrative settlements and adjustments of such claims; and third, cases in which individual claims are adjusted by private acts of Congress.

In the first group, i.e., cases in which a judicial remedy is accorded, admiralty and maritime torts constitute the principal item. By the Act of March 9, 1920, it was provided that a libel in admiralty in personam might be brought against the United States or against any corporation in which the United States owned the entirc outstanding capital stock, in respect to any matter involving a vessel owned by the United States or by such corporation, if the vessel was employed as a merchant vessel or was a tugboat operated by such corporation. The statute further provided that the proceeding might be maintained in such an instance, if such a proceeding would lie in a case involving a vessel privately owned or operated, ${ }^{17}$ and that such suit should be brought in a district court of the United States. Thus, under this statute, sometimes known as the "Suits in Admiralty Act," the United States may be sued in admiralty on any cause of action involving any ship employed by it as a merchant vessel, to the same extent to which a private person would be liable under similar circumstances. The principal limitation is that the libel in admiralty may be brought only in personam and may not be prosecuted in rem.

Judicial construction has, however, imposed a further limitation to the effect that a proceeding under the "Suits in Admiralty Act" may be maintained only when the

${ }^{18} 43$ STAT. Irx2 (I925), 46 U. S. C. $\$ 78$ I (I940).

17 The foregoing provisions, Act of March 9, 1920, $\$ \$ 1,2,4 I$ STaT. 525, 46 U. S. C. $\$ \$ 741,742$ (1940), read as follows:

\$741: "Exemption of United States vessels and cargoes from arrest or seizure." No vessel owned by the United States or by any corporation in which the United States or its representatives shall own the entire outstanding capital stock or in the possession of the United States or of such corporation or opcrated by or for the United States or such corporation, and no cargo owned or possessed by the United States or by such corporation, shall, in view of the provision herein made for a libel in personam, be subject to arrest or seizure by judicial process in the United States or its possessions: Provided, That this chapter shall not apply to the Panama Railroad Company."

\$742: "Libel in personam. In cases where if such vessel were privately owned or operated, or if such cargo were privately owned and possessed, a proceeding in admiralty could be maintained at the time of the commencement of the action herein provided for, a libel in personam may be brought against the United States or against such corporation, as the case may be, provided that such vessel is employed as a merchant vessel or is a tugboat operated by such corporation. Such suits shall be brought in the district court of the United States for the district in which the parties so suing, or any of them, reside or have their principal place of business in the United States, or in which the vessel or cargo charged with liability is found. . . Upon application of either party the cause may, in the discretion of thr court, be transferred to any other district court of the United States." 
vessel involved is in a port of the United States or one of its possessions. ${ }^{18}$ This conclusion was reached by the following reasoning: Sections $I$ and 2 of the Act are in pari materia; Section I in effect prohibits seizure of a vessel of the United States in a proceeding in rem and substitutes a remedy in personam; and, since the Congress has no power to provide immunity from seizure in respect to such vessels when in foreign ports, the provision authorizing a suit in personam, being a substitute for a libel in rem, must necessarily exclude any case involving a vessel which is not in a port of the United States or one of its possessions. It has been further held that the remedy provided by this Act is exclusive, and that consequently no suit in respect to any cause of action cognizable thereunder may be maintained in the Court of Claims. ${ }^{10}$

By the Act of March 3, I925, the liability of the United States for admiralty and maritime torts was extended to cases involving public vessels of the United States. ${ }^{20}$ By judicial construction, this act has been held inapplicable to claims on the part of naval personnel, in view of the fact that there is a special statute authorizing reimbursement of members of the naval forces for loss or destruction of personal property and another statute creating a pension system for them. ${ }^{21}$ The venue provisions of the statute expressly permit suit to be brought in cases involving vessels or cargoes outside of the territorial waters of the United States. Consequently the limitation imposed by the courts on suits relating to merchant vessels to the effect that no action lies if such vessel is outside of the territorial waters of the United States, does not apply when a public vessel is involved.

The result of the two statutes just discussed is that the United States is suable in admiralty in the district courts of the United States by a libel in personam in respect to any admiralty or maritime tort. There are three limitations on this jurisdiction: first, the jurisdiction does not extend to claims on the part of naval personnel; second, it does not apply to cases involving merchant vessels of the United States that are outside of the territorial waters of the United States or its possessions; and third, such actions may not be maintained in the Court of Claims, but may be brought only in the District Courts. There is no limitation on the amount of a claim of which the courts may take cognizance or on the amount that may be recovered. The jurisdiction has been frequently invoked. For example, on June 30, I94I, there were 206 actions pending under the Suits in Admiralty Act and I8 under the Public Vessels Act. By contrast, it is a strange anomaly and peculiar incongruity that in respect to common-law torts the United States still maintains its sovereign immunity practically undiminished.

${ }^{18}$ Blamberg Bros. v. U. S., 260 U. S. 452 (1923).

${ }^{10}$ Johnson v. U. S. Shipping Board Emergency Fleet Corp., 280 U. S. 320 (1930).

${ }^{30} 43$ STAT. III2 (I925) 46 U. S. C. \$781 (1940): "Libel in admiralty against or impleader of United States. A libel in personam in admiralty may be brought against the United States, or a petition impleading the United States, for damages caused by a public vessel of the United States, and for compensation for towage and salvage services, including contract salvage; rendered to a public vessel of the United States: Provided, That the cause of action arose after the 6th day of April, r920."

${ }^{21}$ Dobson v. U. S., 27 F. (2d) 807 (C. C. A. $2 d$, r928). 
By the Act of June 25, I9I0, which was amended and broadened by the Act of July I, IgI8, the United States submitted itself to suit in the Court of Claims for what in the case of a private person would be considered infringement of a patent. ${ }^{22}$ The jurisdiction of the Court of Claims is exclusive and such actions may not be maintained in district courts. Persons who make an invention while in the. employment or service of the United States Government are barred from the benefits of the Act in respect to such invention. As indicated above, the peculiar phraseology of the statute has led the courts to intimate that a suit against the United States in the Court of Claims for the use of a patented invention is an action to recover just compensation for the taking by eminent domain of a license to use the invention. ${ }^{23}$

Section I3 of the River and Harbors Act of $1935,{ }^{24}$ conferred on the Court of Claims "jurisdiction to hear and determine claims for damages to oyster growers upon private or leased lands or bottoms arising from dredging operations and use of other machinery and equipment in making such improvements." Damages to oyster beds caused by dredging operations appear to be the only type of commonlaw torts, as distinguished from admiralty and maritime torts, in respect to which the United States, by a statute of general application, has submitted itself to be sued. An examination of the records discloses that only one action has been instituted under this provision of law.

Another group of tort claims in respect to which a judicial remedy is accorded is that which comprises claims arising out of the activities of Government-owned or Government-controlled corporations. While to all intents and purposes, such corporations as the Emergency Fleet Corporation, the Reconstruction Finance Corporation, and the Home Owners' Loan Corporation, to cite but a few, perform functions which otherwise would be performed by Government departments, and from the standpoint of the public their status appears to be that of governmental agencies, they are, nevertheless, regarded as separate legal entities. At first, considerable conflict arose in the decisions of the lower courts on the question whether the governmental immunity to suit extended to such corporations. This question has recently been definitely determined in the negative. It has been held by the Supreme Court that such a corporation may be sued in respect to torts in the same manner as a

\footnotetext{
${ }^{22} 36$ STAT. 851 (I9I0), 40 STAT. 705 (I9I8), 35 U. S. C. $\$ 68$ (1940). "Suit for unlicensed use of invention by the United States; compensation for; Government employees. Whenever an invention de. scribed in and covered by a patent of the United States shall be used or manufactured by or for the United States without license of the owner thereof or lawful right to use or manufacture the same, such owncr's remedy shall be by suit against the United States in the Court of Claims for the recovery of his reasonable and entire compensation for such use and manufacture. The Court of Claims shall not entertain a suit or award compensation under the provisions of this section where the claim for compensation is based on the use or manufacture by or for the United States of any article owned, leased, used by, or in the possession of the United States prior to June 25, 1910. In any such suit the United States may avail itself of any and all defenses, general or special, that might be pleaded by a defendant in an action for infringement, as set forth in this chapter, or otherwise. The benefits of the provisions of this section shall not inure to any patentee who, when he makes such claim, is in the employment or service of the Government of the United States, or the assignee of any such patentee. 'This section shall not apply to any device discovered or invented by such employee during the time of his employment or service."

${ }^{23}$ Crozier v. Fried. Krupp A. G., 224 U. S. 290 (1912).

${ }^{24} 49$ STAT. 1028, 1049 (1935), 28 U. S. C. \$250-a (1940).
} 
private corporation and its liability is governed by the same rules of substantive law. ${ }^{25}$ The result of this doctrine is to place a large group of tort claims arising out of governmental activities within the reach of a judicial remedy.

In addition, a judicial remedy by suit either in the Court of Claims or in a district court of the United States is frequently accorded to specified persons, in respect to particular claims, by special acts of Congress. Legislation of this type will be later discussed.

We may now proceed to a discussion of the second group of tort claims against the United States, namely, those that may be settled and adjusted administratively. The large number of claims involving personal injuries sustained by Government employees in the performance of their duties are adjusted under the Federal Employees' Compensation Act by the United States Employees' Compensation Commission, pursuant to a compensation scale prescribed by the statute. ${ }^{26}$ The theory and operation of this law are similar to those of state workmen's compensation acts. Compensation for personal injuries sustained in the course of the performance of their duties is paid to Government employees, irrespective of whether the injury was due to any negligence on the part of the employer. The Supreme Court has observed that "this Compensation Act is the expression of a slowly developed purpose on the part of the United States to give compensation to its employees who otherwise would be without remedy when injured by fault of the Government."27 Just as workmen's compensation laws have withdrawn from the ordinary processes of the courts a large category of tort claims, so the Federal Employees' Compensation Act makes unnecessary any judicial remedy in respect to claims of a similar type affecting Government employees. It must be observed, however, that this act does not benefit the entire Government personnel. Its provisions are restricted to "employees of the United States" and do not cover "officers of the United States," as well. There is a sharp distinction between these two classes. Although the latter is much less numerous than the former, it, nevertheless, comprises a considerable proportion of Government personnel, who find themselves without a right or remedy to secure compensation for any personal injuries sustained by them in the course of the performance of their duties, whether or not caused by the negligence of the Government. There are instances on record in which several persons attached to the Government, traveling on official business, were simultaneously injured in the same accident. Those of them who had the status of employees of the Government received compensation under this Act, while those who had the higher status of officers of the Government found themselves without a remedy.

By the Act of December 28, I922, which is sometimes known as the "Small Tort Claims Act,"28 the head of every federal department or establishment is authorized

${ }^{26}$ Keifer and Keifer v. Reconstruction Finance Corp., 306 U. S. 381 (1939); Sloan Shipyards Corp. v. U. S. Shipping Board Emergency Fleet Corp., 258 U. S. 549 (I922); Prato v. Home Owners' Loan Corp., 106 F. 2 d 128 (C. C. A. Ist, 1939).

${ }_{20} 39$ SтAT. 742 (I9I6), 5 U. S. C. \$\$75I-798 (1940).

27 Dahn v. Davis, 258 U. S. 42 I (rg22).

${ }_{42}^{28}$ STAT. 1066 (1922), 3I U. S. C. $\$ \$ 215-217$ (I940). 
to consider, ascertain, adjust and determine any claim on account of damages to or loss of privately owned property, if the amount of the claim does not exceed \$10oo, caused by the negligence of any officer or employee of the Government acting within the scope of his employment. Any amount found to be due to any claimant is certified to the Congress as a legal claim for payment out of appropriations that may be made by the Congress therefor. It will be observed that the authority granted by this act is limited to claims for property damage, and does not comprise personal injuries. The result of this distinction has often proved anomalous. For example, in cases involving damages caused by the negligence of the driver of a Government vehicle, the administrative agency by which the driver is employed is in a position to adjust such items of the claim of the injured party as involve property damage, but is constrained to ignore items of personal injuries, such as medical and hospital expenses, pain and suffering, compensation for permanent injuries, etc. In addition, the limitation on the amount of the claim that may be entertained leaves without remedy cases in which the claimant has suffered serious consequences as the result of the negligence of a Government employee. It should also be noted that the Act does not authorize the Government agency to make direct payment of any amount found to be due, but requires the finding to be certified to the Congress in order that an appropriation may be made for that purpose.

It has been held that although the statute refers to privately owned property, it should be construed as applicable to claims on the part of municipalities, on the theory that with relation to the federal government property owned by states and municipalities is private property. ${ }^{29}$ In considering claims under this act, divergencies developed between the various governmental agencies with respect to claims of insurance companies based on the right of subrogation. Some agencies declined to entertain such claims, on the ground that the probable purpose of the Congress was to reimburse the owner of the property for his loss and that it was not contemplated that an insurance company, which was paid a premium for carrying the risk, should be permitted to avail itself of the benefits of the statute. Other agencies followed the opposite practice, in view of the fact that the statute is not limited in its terms and claims based on the right of subrogation are not excluded. This question was submitted to the Attorney General for an opinion, who, on June 29, 1932, ruled that the statute should be construed as authorizing the determination and certification of such claims. ${ }^{30}$

In addition to the general law just discussed, there are numerous statutes conferring upon specific agencies the authority to adjust claims of a particular type. Some provisions of this class constitute permanent legislation, while others are carried in appropriation acts. Without attempting to make an exhaustive enumeration of such laws, attention will be directed to the more important statutes in this category.

The Secretary of State is authorized by the Act of February ${ }_{13}, 1936,{ }^{31}$ to settle

${ }^{29} 38$ OPS. ATT'Y GEN. $5{ }^{2} 4$ (1936).

${ }^{31} 49$ StAT. Ix39, 3I U. S. C. $\$ 224$ (a) (1940).

${ }^{30}{ }_{36}$ Id. 553 (1932). 
any claims for personal injuries or death of any person who is not an American national, in any foreign country in which the United States exercises privileges of extra-territoriality, if the injury or death was due to any act or omission of any officer, employee or agent of the United States. Persons in the employ of the United States are excluded from the benefit of the act. Any amount found to be due to any claimant is to be certified to the Congress for payment out of appropriations that may be made therefor. This statute was enacted at the request of the State Department for the benefit of Chinese claimants. ${ }^{32}$

The Secretary of the Treasury is authorized by the Act of June $15,1936,{ }^{33}$ to adjust claims not exceeding $\$ 3000$ in amount for damages occasioned by collisions incident to the operation of vessels of the United States Coast Guard or of the United States Public Health Service. Any amount determined to be due any claimant is to be certified to the Congress for payment out of appropriations that may be made therefor.

The Secretary of War is authorized by various statutes to settle several classes of claims. He may pay compensation for loss, damage or destruction of private property belonging to members of the military personnel, if such property is lost, damaged or destroyed while being shipped on board an unseaworthy vessel, by order of an officer authorized to give such order or direct such shipment. ${ }^{34}$ This liability is, however, limited only to such articles as the Secretary of War shall decide to declare to be reasonable, useful, necessary and proper for the owner to have in his possession while in quarters or in the field, engaged in the public service in the line of duty. ${ }^{\mathbf{3 5}}$

By another statute the Secretary of War is authorized to settle claims not exceeding $\$ 500$ for damages to and loss of private property incident to the training, practice, operation or maintenance of the army. Claims so approved are transmitted to the General Accounting Office, which makes payments upon the Secretary's recommendation. ${ }^{36}$ The Secretary of War may also settle claims not exceeding $\$ 25^{\circ}$ in amount for damages to persons and private property resulting from the operation of aircraft either at home or abroad. ${ }^{37}$ The law requires such claims to be substantiated by survey reports of a board of officers appointed by the commanding officer of the nearest aviation post and to be approved by the Chief of the Air Service and the Secretary of War.

In addition, the Secretary of War is permitted to adjust certain claims for damages arising from causes which cannot properly be considered torts committed by the United States, as, for instance, for property lost in saving human life or property belonging to the United States, or for property destroyed or captured by the enemy. ${ }^{38}$

The Attorney General is authorized by the Act of March 20, 1936,39 to adjust claims not exceeding $\$ 500$ in amount, on account of damages to persons or privately owned property caused by any member of the investigative personnel of the Federal

\footnotetext{
${ }^{32}$ See Sen. Rep. No. 751, 74th Cong., Ist Sess. (1935).

3I 49 STAT. 15I4, I4 U. S. C. \$7I (I940). 31 U. S. C. \$\$2I8-22I (1940).

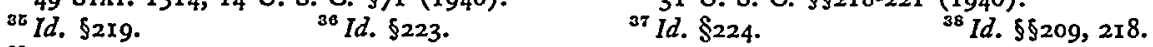

${ }^{30} 49$ STAT. II 84,3 U. S. C. $\$ 224$ (b) (1940).
} 
Bureau of Investigation, acting within the scope of his employment. Amounts found due are certified to the Congress for payment out of appropriations that may be made therefor.

The Postmaster General is authorized to adjust and settle any claim not exceeding $\$ 500$ for damages caused to person or property by or through the operation of the Post Office Department in any branch of its service.0 The statute conferring this authority expressly extends the power to cases of damages caused by the negligence of any officer or employee of the Post Office Department or the Postal Service acting within the scope of his employment.

The Secretary of the Navy is empowered to adjust several classes of claims. By one provision of law, he is authorized to adjust and pay amounts not exceeding $\$ 500$ due in respect to claims for damages to and loss of privately owned property, if men in the Naval Service or Marine Corps are found to be responsible for the damage or loss. ${ }^{41}$ Losses and damages occasioned by naval vessels are, however, expressly excluded from this statutory provision since such claims are covered by another statute, authorizing the Secretary of the Navy to adjust claims, not exceeding the sum of $\$ 3000$, for damages occasioned by collisions or such as are incident to the operation of vessels of the Navy, if vessels of the Navy or in the Naval Service are found to be responsible for such damages. It should be pointed out that in this group of cases the Secretary of the Navy is without power to make direct payment to the claimants, but is required to report to the Congress, through the Treasury Department, the amount ascertained and determined to be due, for payment out of appropriations that may be made therefor. ${ }^{42}$ It should be borne in mind that suit may be also maintained in the district courts for damages caused by a Naval vessel. ${ }^{43}$ The Paymaster General of the Navy is empowered to reimburse members of the Naval personnel for loss or destruction of or damage to person or property caused under certain circumstances enumerated in the statute governing such matters. ${ }^{44}$

The Secretary of the Interior is empowered to pay damages caused to owners of lands or other private property by reason of governmental operations in the survey, construction, operation, or maintenance of irrigation works in connection with Indian irrigation projects. ${ }^{45}$ It will be observed that unlike most other statutes of this type, the Act here in question contains no maximum limitation on the amount of the claim that may be paid thereunder, except that the total of such claims settled in any one year may not exceed five percent of the funds available for the project under which they arise.

With the approval of the Secretary of Commerce, the Director of Coast and Geodetic Survey may adjust claims not exceeding $\$ 500$ in amount for damages occasioned by acts for which the Coast and Geodetic Survey is found to be responsible. ${ }^{46}$ The amounts determined to be due are reported to the Congress through the

\footnotetext{
${ }^{40} 31$ U. S. C. $\$ 224$ (c) (1940). $\quad{ }^{41} 34$ U. S. C. $\$ 600$ (1940).

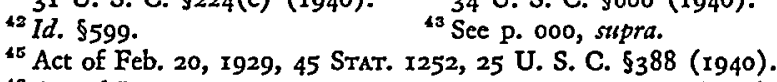

" 34 U. S. C. $\$ 98 x$ (1940)

${ }^{48}$ Act of June 5, 1920, 4I STAT. 929, 1054, 33 U. S. C. $\$ 853$ (1940).
} 
Treasury Department for payment out of appropriations that may be made therefor.

The Secretary of Agriculture is authorized to reimburse owners of private property for damage or destruction thereof caused by Government employees in connection with the protection, administration or improvement of the national forests. No payment in excess of $\$ 500$ may be made in respect to any such claim. ${ }^{47}$

It will be observed that practically all of the statutes just summarized contain a limitation on the amount of claims that may be entertained. Generally, the authority is restricted to payment of claims involving comparatively small sums of money. In many instances, the authority is limited to claims for property damage and does not comprise claims for personal injuries. In some instances, the head of the department is empowered to make direct payment of the claim adjusted by him. In other cases, he is required to certify to the Congress the amount which he finds to be due. In every instance, the matter is handled in an administrative manner. The action of the head of the department is not subject to review at the behest of the claimant. No judicial remedy is accorded. Neither is there any provision for administrative hearings. The actual practice is to determine such matters on the basis of affidavits submitted by the claimant and written reports of the Government employees and statements of other witnesses.

There is still another statute of general application. It provides that when there is filed in the General Accounting Office a claim or demand against the United States that may not lawfully be adjusted by the use of an appropriation theretofore made, but which, in the judgment of the Comptroller General, contains such elements of legal liability or equity as to be deserving of the consideration of the Congress, the Comptroller General is required to submit such claim to the Congress by a special report. ${ }^{48}$ This statute is but infrequently invoked.

Obviously, there remains a large group of cases in respect to which neither a judicial nor an administrative remedy is accorded. Claims in this category are adjusted, if they are satisfied at all, by means of private acts of Congress. Ordinarily, each of such measures relates to a specific claim and grants relief to a named beneficiary or beneficiaries. Bills of this class are introduced in large numbers in each Congress. An average of only approximately twenty percent of them are enacted. Frequently, because of the volume of such legislation, several years elapse before a meritorious claim is adjusted. Just as an indication of the extent of such legislation, a computation shows that the 76 th Congress, i.e., r939-r940, passed 282 private acts, which related to claims of a type that would be cognizable judicially if the United States were suable in tort. ${ }^{49}$ Of this number, 79 acts related to claims arising out of the activities of the Works Projects Administration; 49 out of the activities of the

${ }^{47}$ Act of May 27, 1930, 46 StAT. 387 , I6 U. S. C. $\$ 574$ (1940).

${ }^{4 B}$ Act of April 10, 1928, 45 STAT. 413, 3I U. S. C. $\$ 236$ (1940).

${ }^{10}$ The foregoing calculation does not include all private acts passed during the 76 th Congress, but only those which involved claims which on the statement of facts contained in the legislation appeared to be based on a tort committed by an employee of the United States acting within the scope of his employment. Numerous other private acts, which obviously on their face involved the payment of gratuities, were excluded from the computation. 
War Department; 27 out of the activities of the Department of Agriculture; 27 involved activities of the Post Office Department; and 20, those of the Department of the Interior. Numerous other governmental agencies were represented by a smaller number of claims.

Private acts disposing of individual claims against the Government may be subdivided into two categories. In the first class, constituting by far the larger number, are measures providing for direct payment of the claims in specified amounts. Out of the 282 acts, mentioned above, passed during the 76 th Congress, 276 were of this type. Upon the passage of such a bill and its approval by the President, payment on the part of the Treasury follows automatically. In the second group are private acts which merely confer upon the named claimant the privilege of suing the Government for damages in respect to a specified claim. Invariably, the legislation designates the court in which the action is to be brought. Sometimes it is the Court of Claims and on other occasions it is a District Court of the United States. Ordinarily, the effect of the legislation is to waive the governmental immunity to suit in tort and to subject the Government to the same liability as that to which a private individual would be subjected under like circumstances. Unless its language expressly indicates the contrary, the act is ordinarily construed as not creating a cause of action or a substantive right. At times, to avoid any doubt or controversy on this point, it is affirmatively provided that the United States shall be liable as a private individual under like circumstances.

Under the doctrine of Erie Railroad Co. $v$. Tompkins, the State in which the cause of action arose governs the disposition of the claim. ${ }^{\text {"1 }}$ At times provisions are included in the private act expressly waiving a substantive defense that the Government might otherwise successfully interpose or creating a substantive liability, thus going further than merely waiving the governmental exemption from suit. ${ }^{52}$ On the other hand, as a matter of protection to the United States, such measures frequently contain maximum limitations on the amount that may be recovered. In addition, those acts which permit suits to be brought in a district court, rather than the Court of Claims, frequently contain a provision to the effect that the action is to be tried according to the rules applicable to action brought under Section 20, paragraph 20 of the Judicial Code. ${ }^{53}$

The provision of law just referred to confers upon district courts jurisdiction concurrent with that of the Court of Claims in respect to claims on contract and other similar matters if the amount of the claim does not exceed $\$ 10,000$ and contains an express direction that all suits brought and tried by virtue of the authority so granted should be tried by the court without a jury. In other words, the effect of the above mentioned provision in a private act is to require that the trial shall be without a jury.

${ }^{50}{ }_{304}$ U. S. 64 (1938). $\quad{ }^{51}$ U. S. v. Durrance, xor F. (2d) 109 (C. C. A. 5th, 1939).

${ }^{62}$ See Butler Lumber Co. v. U. S., 73 Ct. Cl. 270 (193I), and Radel Oyster Co. v. U. S., 78 Ct. Cl. $8 \mathrm{I} 6$ (1934).

${ }_{63} 28$ U. S. C. $\$ 4 \mathrm{I}(20)(1940)$. 
The law also authorizes either House of Congress to refer to the Court of Claims any pending bill for the payment of a claim against the United States, other than that for a pension. ${ }^{54}$ This may be accomplished by a resolution of a single House. Upon such a reference, the Court of Claims proceeds in the same manner as it would in an action over which it has general jurisdiction, except that instead of rendering a final judgment it makes findings of facts and conclusions of law and reports them to the Congress. If on the basis of such findings and conclusions, the Congress considers the claimant entitled to an award from the Government, a special act is then passed providing for the payment of such amount as is deemed to be due. The findings of the Court of Claims in such instances are purely advisory, the court for that purpose acting as an agent of the Congress. ${ }^{55}$

Congressional procedure in handling private bills is of interest. In both the Senate and House of Representatives there is a Committee on Claims, to which is referred every private bill involving a claim against the Government. These Committees transact their business in a systematic, quasi-judicial manner. The claimant either directly or through the member who introduced the measure, or through his counsel, submits to the Committee written evidence in support of the claim. Such evidence may consist of affidavits, receipts and other similar material. It may be, and frequently is, transmitted by mail. When a bill is about to be reached for consideration by the Committee, it is referred for a report to the government department out of whose activities the claim originated. In due course, the department submits a written report to the Committee, by mail, generally setting forth a detailed statement of the pertinent facts as known to the department, and making a recommendation as to the merits of the claim. In most instances, no oral hearings are held, but the matter is disposed of on the basis of the file consisting of the material submitted by the claimant and the departmental report. When the file is complete and the bill is ready for consideration, it is referred to a subcommittee for study. In most cases, the subcommittee consists of one member, who makes a report to the full Committee. If the Committee determines to report the bill favorably, the member constituting the Subcommittee or the Chairman of the Subcommittee if the Subcommittee consists of more than one member, is generally assigned to prepare the committee report and file it with the Senate or the House, as the case may be. If the action of the Committee is adverse to the legislation, the bill is not reported at all. Occasionally, the subcommittee accords an oral hearing to the claimant, if so requested, but this course is the exception rather than the rule. The Committees on Claims perform their work conscientiously and thoroughly, and almost invariably take a quasi-judicial attitude toward the claims. Their reports are frequently exhaustive and partake of the nature of judicial opinions. In view of the tremendous volume of business with which the Committees are confronted, however, at times many months are consumed after a bill is introduced before it can be reached for

¿4 28 U. S. C. $\$ 257$ (1940).

${ }^{\amalg}$ Pocono Pines Assembly Hotels Co. v. U. S., 73 Ct. Cl. 447,488 (1932). 
consideration. Sometimes delays are encountered by the Committees in securing departmental reports.

The committee procedure is approximately the same in each House. The manner in which the legislation is handled after it leaves the Committee is, however, radically different in the Senate and House of Representatives. In the Senate, there is but a single calendar. All bills of every kind, public and private, are placed on the calendar after they are reported by a committee, in the chronological order in which the reports are submitted. At intervals, generally a few weeks apart, the entire calendar is called. Each bill, as it is called, is considered as passed by unanimous consent, unless one or more senators interpose an objection or ask that it go over. In that event, the bill retains its place on the calendar and is reached for action again on the next call. This process may be repeated numerous times in respect to a measure that is considered objectionable by one or more senators. Ordinarily, however, most of the senators are willing to accept the judgment of the Committee on Claims in respect to the average private bill, and the majority of such measures are passed without objection on the first occasion on which they are called on the calendar.

The procedure in the House of Representatives is, necessarily, more complicated, owing to the fact that it is a much larger body than the Senate. There are four calendars in the House, known respectively as the Union Calendar, the House Calendar, the Consent Calendar, and the Private Calendar. All private bills are placed on the Private Calendar, in the chronological order in which they are reported by the Committee in charge of the legislation. The Private Calendar is called on the first and third Tuesdays of each month. If two or more members object to the consideration of any bill as it is called, it is recommitted to the Committee. If no objection is made, or if only one member objects, the bill is automatically regarded as having been passed by the House. ${ }^{56}$ In order to avoid the operation of the maxim that "what is everybody's business is nobody's business," a practice has grown up under which several Democratic and several Republican members of the House are selected by each of the two groups to act as "official objectors." These members undertake to study all bills on the Private Calendar and to object to such of them as they believe should not be enacted. While this procedure operates reasonably well, its drawback consists in the fact that any two members of the House may by their objections preclude the consideration of a private bill. As a safety-valve, the rules contain still a further provision authorizing the Committee on Claims to report an omnibus bill, consisting of private bills which have been brought up for consideration on the Private Calendar and have been objected to by two or more members and thereby recommitted to the Committee. Such an omnibus bill may include as many items of this type as the Committee deems proper. The bill is considered paragraph by paragraph, each comprising a separate private bill. The bill may be amended by striking out any paragraph as it is reached for consideration. Such an amendment may, however, be adopted only by a vote of the majority of those present and final

${ }^{58}$ Rule XXIV, $\$ 6$ of the House of Representatives. 
action on the omnibus bill is also had by a majority vote. This additional step in the procedure, therefore, accords an opportunity to a claimant to have his claim disposed of by a majority vote. After an omnibus bill is passed, each paragraph is considered as a separate and distinct bill and the omnibus bill thereupon becomes separated into its component parts. The legislation is transmitted to the Senate or the President, as the case may be, not in the shape of an omnibus bill, but in the form of separate, individual bills which composed the omnibus bill.

The numerous steps through which a private bill must successively pass assure the sifting out of claims which are lacking in merit.

After a private bill has passed both Houses, it is submitted to the President for final action, as required by the Constitution in respect to all legislation. During the ten-day period allowed by the Constitution for approval or veto of legislation, the President secures a report and recommendation in respect to the measure from the Bureau of the Budget, which also procures for him reports and recommendations from the department or departments out of whose activities the claim arose, as well as at times from the Department of Justice. With this material before him, as well as the reports of congressional committees concerning the legislation, the President makes his decision. Not infrequently, such a bill encounters a veto, if the claim appears to be one which the Government is under no legal or moral obligation to meet or if the amount to be awarded appears to be excessive. The President's function in such instances is somewhat analogous to that of a trial judge in passing on a motion to set aside the verdict of a jury or of an appellate tribunal in determining whether or not to affirm the decision of a trial court.

The Committees on Claims are conscientious and painstaking in their work. Nevertheless, the nature of the legislative process is such that inordinate delays are at times encountered in the recognition and adjustment of meritorious claims. Congestion of business in the Claims Committee is only one element contributing to that result. In order that a bill may become law, it must receive favorable action by both Houses during the same Congress. Not infrequently a bill may be passed by one House without being reached for action by the other House, during the same twoyear period. With the convening of a new Congress, the legislation must be reintroduced and all the steps that had been previously taken must be retraced from the beginning. There are numerous instances of private bills that have passed each House several times, without being passed by both Houses during the same Congress. It is not at all unusual for private legislation to be enacted which relates to a claim that arose many years previously.

By a message sent to the Congress on January I4, I942, the President recommended legislation expanding ${ }^{57}$ the existing authority of the executive departments and independent establishments to adjust and determine tort claims against the Government and empowering the district courts to entertain suits against the United

\footnotetext{
${ }^{57}$ See Armstrong and Cockrill, The Federal Tort Claims Bill, infra p. 327.
} 
States in respect to claims of this nature involving amounts not exceeding $\$ 7500$. In discussing this subject, the President stated:

During the past 20 years, Members of the Congress have frequently pointed out that the procedure for relief of tort claims by special act is slow, expensive, and unfair both to the Congress and to the claimant, and several attempts have been made to enact legislation submitting all negligence claims to administrative or judicial determination.

In summarizing his recommendation, the President observed that the legislation he suggested would "make available a means of dispensing justice simply and effectively to tort claimants against the Government and give them the same right to a day in court, which claimants now enjoy in fields such as breach of contract, patent infringement, or admiralty claims." 